This document is the accepted manuscript version of the following article: Chen, G., Hofstetter, T. B., \& Gorski, C. A. (2020). Role of carbonate in thermodynamic relationships describing pollutant reduction kinetics by iron oxide-bound Fe2. Environmental Science and Technology, 54(16), 10109-10117. https://doi .org/10.1021/acs.est.0c02959

\title{
The role of carbonate in thermodynamic relationships describing pollutant reduction kinetics by iron oxide-bound $\mathrm{Fe}^{2+}$
}

Gongde Chen, ${ }^{1}$ Thomas B. Hofstetter, ${ }^{2,3}$ and Christopher A. Gorski ${ }^{1, *}$

${ }^{1}$ Department of Civil \& Environmental Engineering, Pennsylvania State University, University Park, Pennsylvania, United States

${ }^{2}$ Eawag, Swiss Federal Institute of Aquatic Science and Technology, Dübendorf, Switzerland

${ }^{3}$ Institute of Biogeochemistry and Pollutant Dynamics (IBP), Swiss Federal Institute of Technology, ETH Zürich, Zürich, Switzerland

* Corresponding author, e-mail: gorski@psu.edu, phone (814) 865-5673, fax (814) 863-7304 


\section{ABSTRACT}

2 The reduction of environmental pollutants by $\mathrm{Fe}^{2+}$ bound to iron oxides is an important process that

3 determines pollutant toxicities and mobilities. Recently, we showed that pollutant reduction rates

4 depend on the thermodynamic driving force of the reaction in a linear free energy relationship that

5 was a function of the solution $\mathrm{pH}$ value and the reduction potential, $\boldsymbol{E}_{\mathrm{H}}$, of the interfacial $\mathrm{Fe}^{3+} / \mathrm{Fe}^{2+}$

6 redox couple. In this work, we studied how carbonate affected the free energy relationship by

7 examining the effect that carbonate has on nitrobenzene reduction rates by $\mathrm{Fe}^{2+}$ bound to goethite

8 ( $\alpha$-FeOOH). Carbonate slowed nitrobenzene reduction rates by inducing goethite particle

9 aggregation, as evidenced by surface charge and particle size measurements. We observed no

10 evidence for carbonate affecting $\mathrm{Fe}^{3+} / \mathrm{Fe}^{2+}$ reduction potentials or the mechanism of nitrobenzene

11 reduction. The linear free energy relationship accurately described the data collected in the presence

12 of carbonate when we accounted for the effect it had on the reactive surface area of goethite. The

13 findings from this work provide a framework for determining why common groundwater

14. constituents affect the $E_{\mathrm{H}^{-}}$-dependence of reaction rates involving oxide-bound $\mathrm{Fe}^{2+}$ as a reductant.

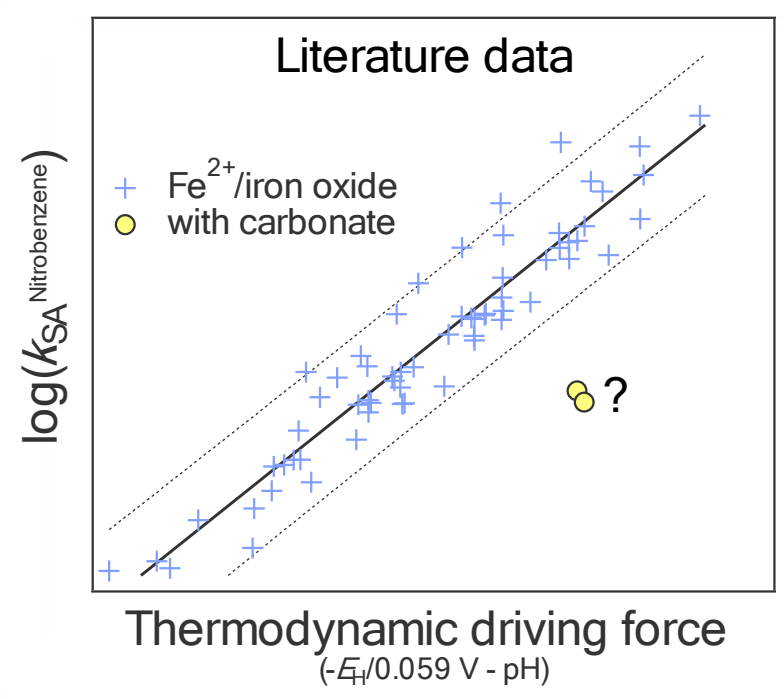




\section{INTRODUCTION}

16 Ferrous iron $\left(\mathrm{Fe}^{2+}\right)$ can reduce and simultaneously alter the toxicities and/or solubilities of several

17 classes of environmental pollutants found in groundwater. ${ }^{1-12}$ Consequently, $\mathrm{Fe}^{2+}$ is a critical

18 reductant to account for in naturally attenuated and engineered remediation systems. ${ }^{13-18}$ Prior work

19 has established that aqueous $\mathrm{Fe}^{2+}$ in the presence of an iron (oxyhydr)oxide (i.e., an "iron oxide")

20 reduces pollutants far more quickly than aqueous $\mathrm{Fe}^{2+}$ alone,, , 9, 14, 19-27 with reduction rates

21 depending on the redox properties of the iron oxide present. ${ }^{2,4-9,14,16,21,28-41}$ This effect is a result

22 of the iron oxide influencing what $\mathrm{Fe}^{3+}$ oxidation product forms. ${ }^{28,30,42,43}$ When aqueous $\mathrm{Fe}^{2+}$

23 oxidizes in the absence of an iron oxide, it tends to form an aqueous $\mathrm{Fe}^{3+}$ complex or ferrihydrite. ${ }^{44}$

24 When $\mathrm{Fe}^{2+}$ oxidizes in the presence of a crystalline iron oxide, however, it tends to form a more

25 thermodynamically stable iron oxide phase, typically via homoepitaxial growth. ${ }^{32,45,46}$ Thus the

26 presence of an iron oxide alters the reduction potential $\left(E_{\mathrm{H}}\right)$ value of the $\mathrm{Fe}^{3+} / \mathrm{Fe}^{2+}$ redox couple by

27 changing the $\mathrm{Fe}^{3+}$ speciation (i.e., the iron oxide that forms).

Recently, we demonstrated that measured $E_{\mathrm{H}}$ values for solutions containing iron oxides and

29 aqueous $\mathrm{Fe}^{2+}$ were fully consistent with those calculated from reference thermodynamic values for

30 the $\mathrm{Fe}^{2+}$ oxidation and mineral growth process, indicating that thermodynamic calculations can be

31 used to accurately estimate $E_{\mathrm{H}}$ values for suspensions containing iron oxides and aqueous $\mathrm{Fe}^{2+} \cdot{ }^{30}$

32 We then showed that the rate constant at which oxide-bound $\mathrm{Fe}^{2+}$ reduced organic compounds

33 depended on the thermodynamic driving for $\mathrm{Fe}^{2+}$ oxidation, as represented by $\boldsymbol{E}_{\mathrm{H}}$ values of

34 suspensions. ${ }^{28}$ Calculated $E_{\mathrm{H}}$ values could be used to construct a linear free energy relationship that

35 correlated reduction rate constants of nitroaromatic compounds by oxide-bound $\mathrm{Fe}^{2+}$, expressed as

36 logarithms of the surface-area-normalized reaction rate constants, $\log \left(k_{\mathrm{SA}}\right)$, to the thermodynamic

37 driving force of the reaction (Section S1, Figure S1A, Table S1): ${ }^{28}$ 


$$
\log \left(k_{\mathrm{SA}}\right)=a \cdot \frac{E_{\mathrm{H}}}{0.059 \mathrm{~V}}+b \cdot \mathrm{pH}+c
$$

where the $E_{\mathrm{H}}$ term is the reduction potential for the half-reaction of $\mathrm{Fe}^{2+}$ oxidation to an iron oxide (shown here for goethite):

$$
\alpha^{-\mathrm{FeOOH}_{(\mathrm{s})}}+\mathrm{e}^{-}+3 \mathrm{H}^{+} \rightleftharpoons \mathrm{Fe}_{(\mathrm{aq})}^{2+}+2 \mathrm{H}_{2} \mathrm{O}
$$

The $\mathrm{pH}$ term in eq. 1 accounts for the proton transfer step(s) to nitrobenzene at or before the ratedetermining step of the reduction reaction. Coefficient $c$ is the $y$-intercept. ${ }^{28}$ The coefficients $a$ and $b$ in eq. 1 were both found to be -1 in our prior work, ${ }^{28}$ which included data from six independent studies using goethite, hematite, lepidocrocite, ferrihydyrite, and/or magnetite. ${ }^{9,}$ 14, 21, 28, 36, 47 The numerical values of these coefficients stand for the consensus reaction mechanism in which proton and electron transfers contribute to the rate-limiting step of oxide-bound $\mathrm{Fe}^{2+}$ oxidation by nitroaromatic compounds. ${ }^{28,48-50}$ Our observation that data for different iron oxides could be fit with a single $c$-term suggested that surface-area normalization of observed rate constants was an adequate procedure to account for reactive oxide-bound $\mathrm{Fe}^{2+}$ sites that interact with nitroaromatic compounds.

In the aforementioned studies, the solutions only contained iron oxide particles, aqueous $\mathrm{Fe}^{2+}$, an organic $\mathrm{pH}$ buffer, and often a background electrolyte. Interestingly, experiments conducted with additional species commonly found in groundwater (i.e., carbonate, humic acid, or a model humic acid) yielded data that deviate from the free energy relationship in that reaction rate constants were higher and lower than predicted by the calculated $E_{\mathrm{H}}$ of the free energy relationship (eq. 1, Figure S1B). ${ }^{39,51-53}$ Understanding why these species cause data to diverge from the free energy relationship is an essential step that must be addressed to use the relationship to describe the reactivity of oxide-bound $\mathrm{Fe}^{2+}$ in natural and engineered environmental systems. The additional species could alter the free energy relationship in two ways. First, they could change the slope of the 
60) free energy relationship (i.e., the $a$ and/or $b$ terms in eq. 1), which represents the relationship

61 between the thermodynamic driving force of the reaction and the reaction rate. ${ }^{28}$ This would occur

62 if the species change the reaction mechanism and/or the rate-limiting step of the reaction. Second,

63 the species could alter the y-intercept (i.e., the $c$ term in eq. 1), which would occur if the species

64. change the number of reactive sites on the iron oxide surface, the frequency of interactions between

65 the electron acceptor and reactive oxide-bound $\mathrm{Fe}^{2+}$ sites, and/or the $\mathrm{Fe}^{2+}$ oxidation product that

66 forms (due to a change in the standard reduction potential, $\boldsymbol{k}_{\mathrm{H}}^{0}$, for the $\mathrm{Fe}^{3+} / \mathrm{Fe}^{2+}$ half reaction).

67 Unfortunately, datasets such as those shown in Figure S1B, lack a sufficient amount of information

68 to conclusively discriminate among these possibilities.

The goal of this work was to determine why groundwater constituents can cause data to

70 deviate from the generalized linear free energy relationship describing organic compound reduction

71 rates with oxide-bound $\mathrm{Fe}^{2+}$. Specifically, we investigated how and why the presence of carbonate

72 causes data to deviate during the reduction of nitrobenzene by $\mathrm{Fe}^{2+}$ bound to goethite. We used

73 nitrobenzene as the model contaminant because it does not sorb or react with iron oxides in the

74. absence of aqueous $\mathrm{Fe}^{2+}$, meaning the nitrobenzene disappearance rate is equal to the reduction

75 rate. ${ }^{51,54}$ We focused on carbonate as a model species and examined how it influenced $\mathrm{Fe}^{2+}$ uptake,

$76 \quad \mathrm{Fe}_{(\mathrm{aq})}^{2+} /$ goethite $\boldsymbol{E}_{\mathrm{H}}$ values, goethite aggregation, goethite surface charges, and nitrobenzene reduction

77 rate constants at different $\mathrm{pH}$ values. Because equilibrium constants are available to describe

78 complexation reactions between $\mathrm{Fe}^{2+}$ and carbonate, ${ }^{33,} 55$ the collected data allowed us to

79 discriminate among the above hypotheses. That is, we could examine how carbonate influenced the

80 free energy relationship between reaction rate constants and the thermodynamic driving force of the

81 reaction in terms of the slope and y-intercept. We conclude by using these data to offer a more 
82 general approach for determining why other groundwater constituents, such as humic acids, alter

83 pollutant reduction rate constants.

\section{MATERIALS AND METHODS}

85 All chemicals were used as purchased, except cyanomethyl viologen, which was synthesized as

86 previously described. ${ }^{56}$ All experiments were conducted at room temperature under anaerobic

87 conditions inside a glovebox (MBraun Unilab Workstation, 100\% $\mathrm{N}_{2}$ atmosphere, $<0.1 \mathrm{ppm} \mathrm{O}_{2}$ ).

88 All aqueous solutions were prepared in deionized (DI) water (Millipore Milli-Q system, resistivity >

$8918 \mathrm{M} \Omega \cdot \mathrm{cm})$ purged with $\mathrm{N}_{2}(>99.99 \%)$ for at least $3 \mathrm{~h}$ before being brought into the glovebox.

The pH buffer solutions contained $25 \mathrm{mM} \mathrm{KCl}$ and $25 \mathrm{mM}$ pH buffer. The pH buffer used

91 at pH 6.0 and 6.5 was 2-N-morpholinoethanesulfonic acid (MES, p $\boldsymbol{K}_{\mathrm{a}} 6.1$, Aresco, $\geq 99 \%$ ) and the

$92 \mathrm{pH}$ buffer used at $\mathrm{pH} 7.0$ was 3-N-morpholinopropanesulfonic acid (MOPS, p $\boldsymbol{K}_{\mathrm{a}}$ 7.2, EMD

93 Chemicals Inc., $\geq 99 \%$ ). Carbonate stock solutions were freshly made inside the glovebox by

94 dissolving solid $\mathrm{NaHCO}_{3}$ in deoxygenated DI water. The stock solutions were kept in sealed glass

95 vials with little headspace to avoid the loss of carbonate to the $\mathrm{N}_{2}$ atmosphere. Ferrous chloride

$96\left(\mathrm{FeCl}_{2}\right.$, Acros, anhydrous, $\left.99 \%\right)$ was received in a sealed ampule and was transferred to the glovebox

97 to make a $0.2 \mathrm{M}$ aqueous $\mathrm{Fe}^{2+}$ stock solution, which was acidified with a few drops of $5 \mathrm{M} \mathrm{HCl}$ to

98 avoid inadvertent oxidation. Cyanomethyl viologen was dissolved in deoxygenated DI water to make

99 a $10 \mathrm{mM}$ mediator stock solution. Nitrobenzene (Reagent grade, Sigma-Aldrich) was transferred to

100 a small amber vial with little headspace and taken into the glovebox to make a $10 \mathrm{mM}$ stock solution

101 in deoxygenated methanol. 


\section{Goethite Synthesis and Characterization}

103 Goethite was synthesized using an established method. ${ }^{57}$ Briefly, $180 \mathrm{~mL} 5 \mathrm{M} \mathrm{NaOH}$ was added to $104100 \mathrm{~mL} 0.1 \mathrm{M} \mathrm{Fe}\left(\mathrm{NO}_{3}\right)_{3}$ solution with vigorous stirring. The suspension was diluted to $2 \mathrm{~L}$ with DI 105 water and heated at $70^{\circ} \mathrm{C}$ for $60 \mathrm{~h}$. The produced solid was washed with DI water by centrifugation, 106 freeze-dried, ground in a mortar, and sieved (200 mesh). The crystal phase of the synthesized 107 goethite was confirmed by X-ray diffraction (Malvern Panalytical Empryean) with a Co irradiation 108 source $\left(\mathrm{K}_{\alpha 1}=1.7890 \AA, \mathrm{K}_{\alpha 2}=1.7929 \AA\right)$ operated at $40 \mathrm{kV}$ and $40 \mathrm{~mA}$. All the diffraction peaks 109 (Figure S2) were consistent with goethite (PDF\# 29-0713). The specific surface area of the goethite $110\left(36 \mathrm{~m}^{2} / \mathrm{g}\right)$ was measured by $\mathrm{N}_{2}$ sorption isotherms in liquid nitrogen (ASAP 2020 Automated Surface 111 Area and Porosimetry System) and calculated by the multi-point Brunauer-Emmett-Teller (BET) $112 \operatorname{method} .^{58}$

\section{$113 \mathrm{Fe}^{2+}$ Uptake and Mediated Potentiometric Measurements}

114 $\mathrm{Fe}^{2+}$ uptake experiments were conducted inside the glovebox by measuring the difference between

115 initial and final aqueous $\mathrm{Fe}^{2+}$ concentrations after an equilibration period. The $\boldsymbol{E}_{\mathrm{H}}$ values of $\mathrm{Fe}_{(\mathrm{aq})^{-}}^{2+}$

116 goethite suspensions were measured using mediated potentiometry. ${ }^{30}$ Specifically, $20 \mathrm{~mL}$ aqueous

117 solutions containing $25 \mathrm{mM} \mathrm{KCl}$ and $25 \mathrm{mM} \mathrm{pH}$ buffer in $20 \mathrm{~mL}$ borosilicate glass vials were spiked 118 with the $\mathrm{Fe}^{2+}$ stock to make initial $\mathrm{Fe}^{2+}$ concentrations ranging from 0.1 to $2.0 \mathrm{mM}$. For experiments 119 containing carbonate, the solution was spiked with an aliquot of 0.1 or $1 \mathrm{M} \mathrm{NaHCO}_{3}$ stock solution 120 to make the desired concentrations ( 1 or $10 \mathrm{mM}$ ). We chose $10 \mathrm{mM}$ as a maximum carbonate 121 concentration to avoid siderite $\left(\mathrm{FeCO}_{3(\mathrm{~s})}\right)$ precipitation $\left(\boldsymbol{K}_{\mathrm{sp}}=10^{-10.55}\right)$ and to be consistent with past 122 studies. ${ }^{33,39,59}$ The pH 6.5 and 7.0 solutions were slightly oversaturated with respect to siderite. We 123 did not observe any loss of $\mathrm{Fe}^{2+}$ from solution that could be attributed to siderite formation in these 124 experiments, consistent with past studies $33,39,59$ and recent work that found siderite nucleation did 
125 not occur under similar experimental conditions. ${ }^{59}$ The solution $\mathrm{pH}$ was adjusted to 7.0 using $1 \mathrm{M}$

$126 \mathrm{NaOH}$ or $\mathrm{HCl}$ solution. Goethite solid was then added to the reactors to reach a mass loading of

$1271.0 \mathrm{~g} / \mathrm{L}$. The reactors were magnetically stirred. After $1 \mathrm{~h}$, an aliquot of cyanomethyl viologen stock

128 solution was added to make a final mediator concentration of $10 \mu \mathrm{M}$. The reactors were sealed with

129 rubber septa and had negligible headspace to prevent carbonate degassing. After mixing in the dark

130 for $24 \mathrm{~h}$, a small portion of each suspension was filtered through a $0.45 \mu$ mylon syringe filter to

131 measure the final aqueous $\mathrm{Fe}^{2+}$ concentration.

The $E_{\mathrm{H}}$ values of $\mathrm{Fe}_{(\text {aq) }}^{2+}$-goethite suspensions were measured using a Pt redox electrode

133 (Metrohm, part 6.0451.100) inside the glovebox. The data was sampled every $2 \mathrm{~s}$ until there was no

134 appreciable change in the measured $E_{\mathrm{H}}$ value over time. The final reading was reported as the $E_{\mathrm{H}}$

135 value of the suspension. The electrode was periodically cleaned with $0.1 \mathrm{M} \mathrm{HCl}$ and calibrated with

136 quinhydrone-saturated $\mathrm{pH}$ buffer solutions at $\mathrm{pH} 4.0$ and 7.0. ${ }^{28,30}$ All measured $\boldsymbol{E}_{\mathrm{H}}$ values were in

137 reference to $\mathrm{Ag} / \mathrm{AgCl}$ and converted in reference to the standard hydrogen electrode (SHE) based

138 on the quinhydrone calibration values. The concentrations of total dissolved $\mathrm{Fe}_{(\text {aq) }}^{2+}$ were measured

139 using the 1,10-phenanthroline method..$^{60}$ The speciation of dissolved $\mathrm{Fe}^{2+}$ was calculated using the

140 thermodynamic database (thermo.Vdb) in Visual MINTEQ software, v3.1. We manually added

141 equilibria reactions for $\mathrm{Fe}\left(\mathrm{CO}_{3}\right)(\mathrm{OH})^{-}$and $\mathrm{Fe}\left(\mathrm{CO}_{3}\right)_{2}^{2-}$, which are not in the MINTEQ

142 database. ${ }^{33,55}$ The concentrations of $\mathrm{Fe}\left(\mathrm{H}_{2} \mathrm{O}\right)_{6(\mathrm{aq})}^{2+}$, which we refer to here as "free $\mathrm{Fe}_{(\mathrm{aq})}^{2+}$ ", were

143 calculated using the chemical equilibrium model (Table S2) in Visual MINTEQ software. The

144 activity coefficients of free $\mathrm{Fe}^{2+}$ for each solution were calculated using the Davies model.

\section{Nitrobenzene Reduction Experiments}

146 Nitrobenzene reduction experiments used the same reactor set-up as mediated potentiometry

147 measurements, except that no mediator was present. We varied the initial $\mathrm{Fe}^{2+}$ concentration $(0.2$ 
148 or $1.0 \mathrm{mM})$, carbonate concentration $(0,1$, or $10 \mathrm{mM})$, goethite loading $(0.25-3 \mathrm{~g} / \mathrm{L})$, and solution

$149 \mathrm{pH}(6.0,6.5$, or 7.0$)$. After a $24 \mathrm{~h}$ equilibrium period between the goethite and aqueous $\mathrm{Fe}^{2+}$, a small

150 aliquot was taken to measure the final $\mathrm{Fe}_{(\mathrm{aq})}^{2+}$ concentration. Nitrobenzene reduction experiments

151 started with the addition of an aliquot of $10 \mathrm{mM}$ nitrobenzene stock solution made in deoxygenated

152 methanol to make an initial nitrobenzene concentration of $\sim 6 \mu \mathrm{M}$. Each reactor was sealed with a

153 Teflon-lined septum and an aluminum crimp cap. At predetermined time intervals, samples were

154 taken and filtered through a $0.2 \mu \mathrm{m}$ PTFE syringe filter. The sampling volume was minimized to

155 prevent $\mathrm{CO}_{2}$ loss into the headspace. The concentrations of nitrobenzene and aniline were

156 measured using high pressure liquid chromatograph (HPLC) with a Supelcosil LC-18 column based

157 on previously established method. ${ }^{30}$

\section{Surface Charge and Particle Size Analysis}

159 The surface charges and aggregate sizes of $\left.\mathrm{Fe}_{(\mathrm{aq})}^{2+}\right)^{-}$goethite suspensions were measured by

160 electrophoretic and dynamic light scattering (Malvern Zetasizer Nano ZS), respectively. The reactors

161 were setup as described above, except that no mediator or nitrobenzene was added. The suspensions

162 contained $0.2 \mathrm{mM} \mathrm{Fe}\left(\begin{array}{c}2+ \\ \text { aq })\end{array}, 1 \mathrm{~g} / \mathrm{L}\right.$ goethite, $0-10 \mathrm{mM}$ carbonate, $25 \mathrm{mM} \mathrm{KCl}$, and $25 \mathrm{mM} \mathrm{pH}$ buffer.

163 We included $\mathrm{Fe}^{2+}$ in these measurements because preliminary measurements demonstrated that

$164 \mathrm{Fe}_{(\mathrm{aq})}^{2+}$ altered goethite aggregation in the presence of carbonate (data not shown). After a $24 \mathrm{~h}$

165 equilibrium period, a portion of each suspension was transferred to cuvettes or zeta potential cells

166 that were sealed inside the glovebox, then taken out for subsequent analysis. The intensity weighted

167 mean hydrodynamic diameter was obtained from an autocorrelation function in a digital correlator

168 using the cumulants method.$^{61}$ Laser diffraction (Mastersizer 3000) measurements were performed

169 under the same conditions, except that the mass loading of goethite was decreased to $0.05 \mathrm{~g} / \mathrm{L}$ to 
170 meet instrument requirements. The surface-weighted mean diameter was collected based on the Mie

171 scattering model ${ }^{62}$

\section{RESULTS AND DISCUSSION}

\section{Effect of Carbonate on Nitrobenzene Reduction Kinetics}

174 We examined the effect of carbonate on nitrobenzene reduction rates by goethite-bound $\mathrm{Fe}^{2+}$ at

175 different $\mathrm{pH}$ values, goethite mass loadings, and initial $\mathrm{Fe}_{(\mathrm{aq})}^{2+}$ concentrations (Table S3). In all 176 experiments, nitrobenzene disappearance followed pseudo-first-order kinetics, consistent with past 177 studies: 28,63

$$
\frac{\mathrm{d}[\mathrm{NB}]}{\mathrm{d} t}=-k_{\mathrm{obs}}[\mathrm{NB}]
$$

179 where $[\mathrm{NB}]$ is the concentration of nitrobenzene $(\mu \mathrm{M})$, and $k_{\mathrm{obs}}$ is the observed pseudo-first-order 180 reduction rate constant $\left(\mathrm{h}^{-1}\right)$. The presence of carbonate slowed the rate of nitrobenzene

181 disappearance, with $k_{\text {obs }}$ values decreasing from $25.8 \pm 0.8 \mathrm{~h}^{-1}$ (no carbonate) to $7.1 \pm 0.4 \mathrm{~h}^{-1}(10$ $182 \mathrm{mM}$ total carbonate) at $\mathrm{pH} 7.0,0.2 \mathrm{mM}$ initial $\mathrm{Fe}_{(\mathrm{aq})}^{2+}$, and $0.5 \mathrm{~g} / \mathrm{L}$ goethite (Figure 1). Nitrobenzene 183 reduction was coupled to aniline production, and a stoichiometric amount of aniline was produced 184 when the reaction was provided sufficient time to proceed to completion (Figure S3). In control 185 experiments lacking goethite, no nitrobenzene disappearance or aniline production occurred over a 186 24-hour period regardless of the carbonate concentration (Figure S4), confirming that goethite187 bound $\mathrm{Fe}^{2+}$ was the responsible species for nitrobenzene reduction, rather than dissolved $\mathrm{Fe}^{2+}$ 188 species. ${ }^{30,64}$ 


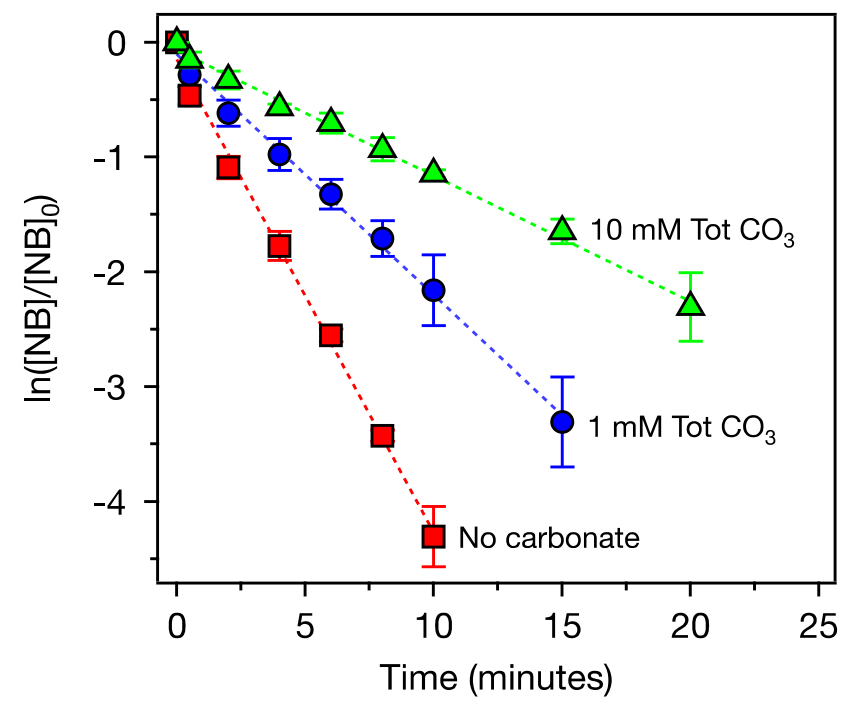

Figure 1. Nitrobenzene (NB) reduction in suspensions containing goethite and aqueous $\mathrm{Fe}^{2+}$ at varied total carbonate concentrations. Reactor conditions: $0.2 \mathrm{mM}$ total $\mathrm{Fe}^{2+}, 0.5 \mathrm{~g} / \mathrm{L}$ goethite, $25 \mathrm{mM}$ MOPS buffer, $25 \mathrm{mM}$ $\mathrm{KCl}$, and $\mathrm{pH}=7.0$. The reactors were equilibrated for $24 \mathrm{~h}$ prior to the addition of $6 \mu \mathrm{M}$ nitrobenzene. Error bars represent the two values measured from duplicate reactors, and points represent the average. Straight lines represent the linear fits with pseudo-first-order kinetic model. of carbonate, the $k_{\mathrm{obs}}$ value $\left(25.8 \pm 0.8 \mathrm{~h}^{-1}\right)$, collected with $0.2 \mathrm{mM}$ total $\mathrm{Fe}^{2+}$ and $0.5 \mathrm{~g} / \mathrm{L}$ goethite,

191 agreed well with our previously reported value $\left(32.3 \pm 0.7 \mathrm{~h}^{-1}\right)$ collected under similar experimental 192 conditions $\left(0.5 \mathrm{mM}\right.$ total $\mathrm{Fe}^{2+}$ and $1 \mathrm{~g} / \mathrm{L}$ goethite) ${ }^{28} \mathrm{We}$ previously found this value was consistent 193 with those compiled from several other studies (Figure S1A). ${ }^{28}$ In the presence of carbonate, 194 however, our reported $k_{\text {obs }}$ value $\left(7.1 \pm 0.4 \mathrm{~h}^{-1}\right)$ was approximately 8 times greater than a value 195 reported in a recent study that used similar experimental conditions with 4 -chloro-nitrobenzene $\left(k_{\mathrm{obs}}\right.$ $\left.196=0.96 \pm 0.09 \mathrm{~h}^{-1}\right) .{ }^{39} \mathrm{~A}$ table detailing the experimental conditions of the two studies is in the 197 Supporting Information (Table S4). The substantially larger $k_{\mathrm{obs}}$ value in our study was surprising 198 given that the goethite surface area loading and the initial $\mathrm{Fe}_{(\mathrm{aq})}^{2+}$ concentration were higher in the 199 cited study ${ }^{39}\left(45 \mathrm{~m}^{2} / \mathrm{L}\right.$ and $\left.0.5 \mathrm{mM}\right)$ than this study $\left(18 \mathrm{~m}^{2} / \mathrm{L}\right.$ and $\left.0.2 \mathrm{mM}\right)$. We examined if this 200 difference was due to the $\mathrm{pH}$ buffer (i.e., MOPS) used in our experiments. ${ }^{31}$ Our solution contained 
$25 \mathrm{mM}$ MOPS and $10 \mathrm{mM}$ total carbonate, whereas the former study used only $10 \mathrm{mM}$ total

202 carbonate. When we performed a nitrobenzene reduction experiment without MOPS, the $k_{\text {obs }}$ value

$203\left(6.5 \mathrm{~h}^{-1}\right)$ was similar to what we observed when $25 \mathrm{mM}$ MOPS was present $\left(7.6 \mathrm{~h}^{-1}\right)$ (Figure S5),

204 indicating that the presence of MOPS could not explain the difference in nitrobenzene reduction

205 kinetics. We suspect that the discrepancy in $k_{\mathrm{obs}}$ values between the studies may be due to the former

206 study using a much higher initial nitrobenzene concentration $(50 \mu \mathrm{M})^{39}$ than what we used $(\sim 6 \mu \mathrm{M})$.

207 We observed that high initial nitrobenzene concentrations in the former study prominently

208 decreased the solution $\mathrm{pH}$ over the course of the reaction because of insufficient buffer capacity

209 offered by $10 \mathrm{mM}$ carbonate, as twelve protons are generated to completely reduce one nitrobenzene

210 molecule to one aniline molecule by $\mathrm{Fe}^{2+}$ bound to goethite. ${ }^{28}$

211 We explored possible explanations for why carbonate decreased nitrobenzene reduction

212 rates in our experiments. We first examined if carbonate slowed nitrobenzene reduction rates by

213 competing with $\mathrm{Fe}^{2+}$ for sorption sites at the goethite surface, as carbonate is known to form surface

214 complexes on goethite at circumneutral $\mathrm{pH}$ values. ${ }^{33,65,66} \mathrm{We}$ compared the extent of $\mathrm{Fe}^{2+}$ uptake

215 on the goethite surfaces in the experiments from Figure 1 and in additional experiments with

216 different goethite mass loadings at pH 7.0 (Table S3). The oxide-bound $\mathrm{Fe}^{2+}$ loadings for $200 \mu \mathrm{M}$

217 initial $\mathrm{Fe}_{(\mathrm{aq})}^{2+}$ were indistinguishable at the different total carbonate concentrations (0 mM: $133 \pm 54$

$218 \mu \mathrm{mol} / \mathrm{g}, n=6 ; 1 \mathrm{mM}: 130 \pm 16 \mu \mathrm{mol} / \mathrm{g}, n=6 ; 10 \mathrm{mM}: 132 \pm 33 \mu \mathrm{mol} / \mathrm{g}, n=7)$, indicating that

219 carbonate did not inhibit $\mathrm{Fe}^{2+}$ uptake by goethite at $0.2 \mathrm{mM}$ total $\mathrm{Fe}^{2+}$. We did, however, observe

220 that carbonate modestly inhibited $\mathrm{Fe}^{2+}$ uptake at higher $\mathrm{Fe}^{2+}$ concentrations $(\geq 0.5 \mathrm{mM})$ at $\mathrm{pH} 7$

221 (Figure 2). Note a prior study found carbonate significantly inhibited $\mathrm{Fe}^{2+}$ sorption on goethite at $\mathrm{pH}$

2227.0 under similar goethite surface area loadings and initial $\mathrm{Fe}^{2+}$ concentrations. ${ }^{33}$ We were unable to

223 reproduce their observation, even when we replicated their experiment (Figure S6). Unfortunately, 


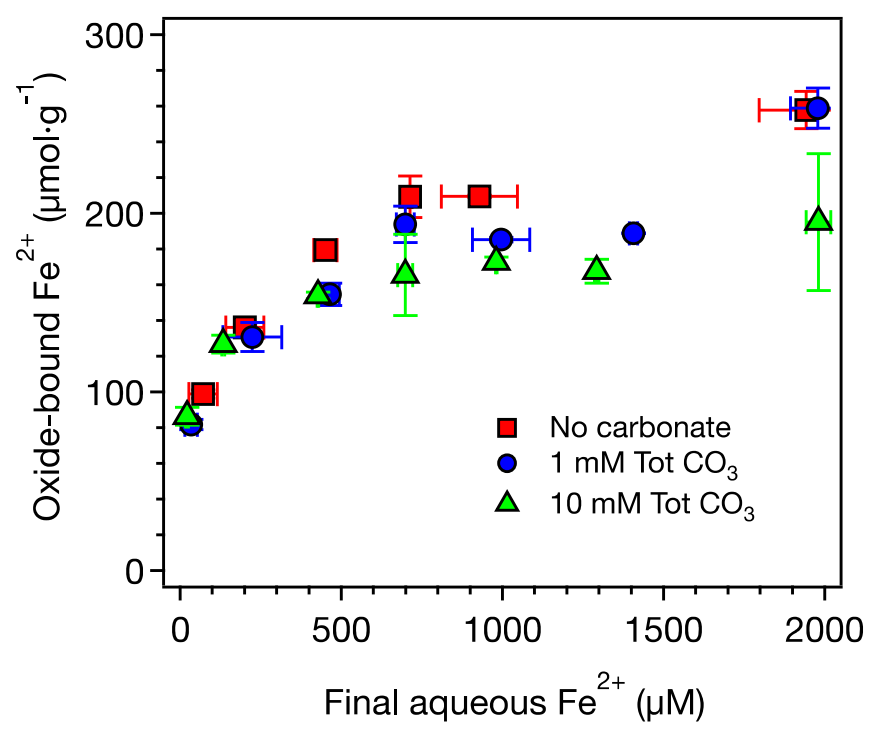

Figure 2. Impact of carbonate on $\mathrm{Fe}_{(\mathrm{aq})}^{2+}$ uptake by goethite at $\mathrm{pH} 7.0$ with a 24-hour equilibration time. Error bars represent the two values measured from duplicate reactors, and points represent the average. Experimental conditions: $1 \mathrm{~g} / \mathrm{L}$ goethite, $25 \mathrm{mM} \mathrm{KCl}, 25 \mathrm{mM}$ MOPS buffer.

224 we were unable to identify why our results differed from those in the previous work. As a result of 225 our experiments, we ruled out the possibility that nitrobenzene reduction was slowed by carbonate 226 because it inhibited $\mathrm{Fe}^{2+}$ uptake (i.e., decreased the number of reactive $\mathrm{Fe}^{2+}$ sites), based on the lack 227 of evidence for inhibition at $0.2 \mathrm{mM} \mathrm{Fe}^{2+}$. This finding led us to examine how carbonate influenced $228 \boldsymbol{E}_{\mathrm{H}}$ values of goethite-bound $\mathrm{Fe}^{2+}$.

230 For each data point in Figure 2, we measured the $E_{\mathrm{H}}$ value of the suspension using mediated 231 potentiometry. Carbonate had a negligible effect on $E_{\mathrm{H}}$ values as a function of the concentration of $232 \mathrm{Fe}\left(\mathrm{H}_{2} \mathrm{O}\right)_{6(\text { aq })}^{2+}$ (i.e., "free $\mathrm{Fe}_{(\mathrm{aq})}^{2+}$ ") at $\mathrm{pH} 7$ (Figure 3). ${ }^{28,67,68}$ Note that we transition here from 233 considering the data in terms of total dissolved $\mathrm{Fe}^{2+}$ to free $\mathrm{Fe}_{(\mathrm{aq})}^{2+}$ because the Nernst equation 234 requires consideration of a specific $\mathrm{Fe}^{2+}$ species. In the presence of carbonate, a portion of the 235 dissolved $\mathrm{Fe}^{2+}$ complexes with carbonate to form $\mathrm{Fe}\left(\mathrm{CO}_{3}\right)\left(\mathrm{H}_{2} \mathrm{O}\right)_{5(\mathrm{aq})}^{0}$ (i.e., $\left.\mathrm{FeCO} \mathrm{C}_{3}^{0}\right)$ and, to a lesser 


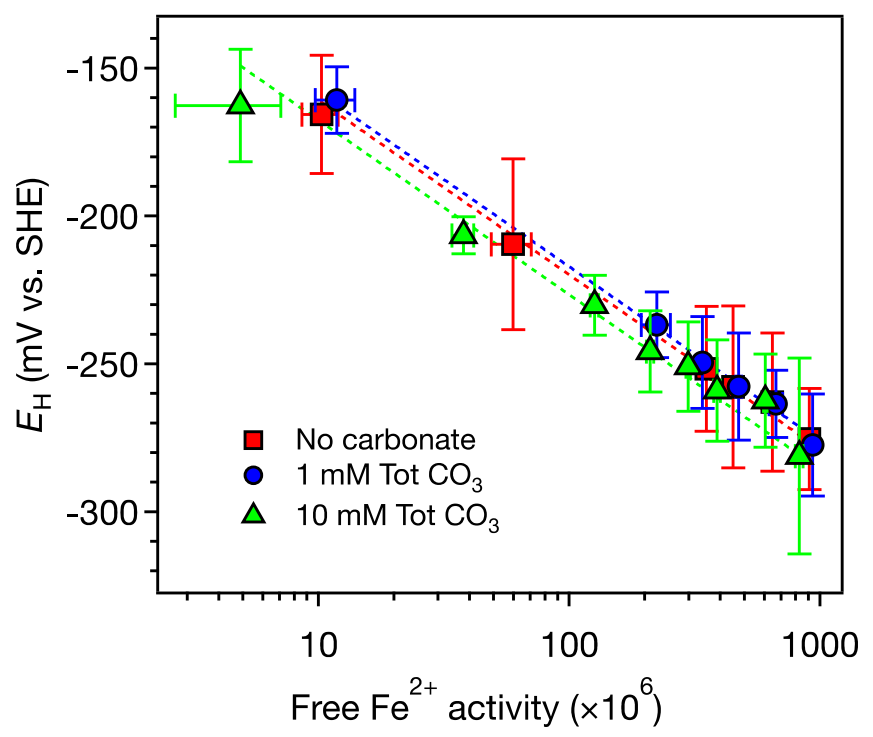

Figure 3. Impact of carbonate on reduction potentials of goethite suspensions as a function of free $\mathrm{Fe}_{(\text {aq })}^{2+}$ activity at $\mathrm{pH}$ 7.0. Error bars represent the two values measured from duplicate reactors, and points represent the average. Experimental conditions: $1 \mathrm{~g} / \mathrm{L}$ goethite, $25 \mathrm{mM} \mathrm{KCl}, 25 \mathrm{mM}$ MOPS buffer, and $10 \mu \mathrm{M}$ mediator. Dash lines represent data fits using eq. 4 .

236 degree, $\mathrm{Fe}\left(\mathrm{HCO}_{3}\right)\left(\mathrm{H}_{2} \mathrm{O}\right)_{5 \text { (aq) }}^{+}$(i.e., $\left.\mathrm{FeHCO}_{3}^{+}\right) .{ }^{55} \mathrm{In}$ the presence of $10 \mathrm{mM}$ total carbonate at $\mathrm{pH} 7$, 237 approximately $35 \%$ of total aqueous $\mathrm{Fe}^{2+}$ will be present as $\mathrm{FeCO}_{3}^{0}$ or $\mathrm{FeHCO}_{3}^{+}$(and $3.5 \%$ at $1 \mathrm{mM}$ 238 total carbonate), which was calculated based on chemical equilibrium model (Table S2) in Visual MINTEQ software, V3.1 (Figure S7). ${ }^{55}$

Prior work has shown aqueous suspensions of goethite and $\mathrm{Fe}_{(\text {aq) }}^{2+}$ reach thermodynamic 241 equilibrium and can be described by the half reaction shown in eq. 2 and the corresponding Nernst 242 equation: ${ }^{30}$

$$
E_{\mathrm{H}}=\boldsymbol{E}_{\mathrm{H}}^{0}-\frac{R T}{F} \ln \left\{\mathrm{Fe}_{(\text {aq }}^{2+}\right\}+3 \frac{R T}{F} \ln \left\{\mathrm{H}^{+}\right\}
$$

244 where $\mathrm{Fe}_{(\mathrm{aq})}^{2+}$ is $\mathrm{Fe}\left(\mathrm{H}_{2} \mathrm{O}\right)_{6(\mathrm{aqq})}^{2+}, R$ is the ideal gas constant, $T$ is temperature, and $F$ is Faraday's constant.

245 At room temperature (298 K), the expression simplifies to:

$$
E_{\mathrm{H}}=E_{\mathrm{H}}^{0}-0.059 \mathrm{~V} \cdot \log \left\{\mathrm{Fe}_{(\text {aq })}^{2+}\right\}-0.177 \mathrm{~V} \cdot \mathrm{pH}
$$


247 Regardless of carbonate concentrations, the measured $E_{\mathrm{H}}$ values were well fit by eq. 5 when assuming

248 the theoretical slope value for $\mathrm{Fe}_{(\text {aq) }}^{2+}$ activity (Figure 3), confirming that goethite and aqueous $\mathrm{Fe}^{2+}$

249 reached thermodynamic equilibrium. Although the free $\mathrm{Fe}_{(\mathrm{aq})}^{2+}$ concentration decreases by $35 \%$ at 10

$250 \mathrm{mM}$ carbonate because of complexation reactions (Figure S7), calculations based on eq. 4 shows

251 that such a change only varies $E_{\mathrm{H}}$ values by $10 \mathrm{mV}$, which is consistent with minor change in $E_{\mathrm{H}}$

252 values experimentally observed (Figure 3). The fitted $\boldsymbol{t}_{\mathrm{H}}^{0}$ values of $\boldsymbol{\alpha}^{-} \mathrm{FeOOH}_{(\mathrm{s})} / \mathrm{Fe}_{(\mathrm{aq})}^{2+}$ redox couple

253 in Figure 3 are $783 \pm 1 \mathrm{mV}$ vs. SHE (no carbonate), $786 \pm 1 \mathrm{mV}$ ( $1 \mathrm{mM}$ total carbonate), and $775 \pm$

$2542 \mathrm{mV}(10 \mathrm{mM})$. The values agree well with previously reported values for goethite $\left(800 \pm 3 \mathrm{mV}^{28}\right.$

255 and $768 \pm 1 \mathrm{mV}^{30}$ ), indicating that carbonate did not affect the $\alpha^{-} \mathrm{FeOOH}_{(\mathrm{s})} / \mathrm{Fe}_{(\mathrm{aq})}^{2+}$ half-reaction.

256 We used the average $\boldsymbol{E}_{\mathrm{H}}^{0}$ value $(781 \mathrm{mV})$ and eq. 5 to calculate $\boldsymbol{E}_{\mathrm{H}}$ values in all subsequent

257 experiments.

\section{Relationship between $\boldsymbol{E}_{\boldsymbol{H}}$ Values and Nitrobenzene Reduction Kinetics}

259 We examined how nitrobenzene reduction kinetics varied as a function of solution $\boldsymbol{E}_{\mathrm{H}}$ and total 260 carbonate concentration (data tabulated in Table S3). We surface-area-normalized the $k_{\mathrm{obs}}$ values 261 following a standard convention: ${ }^{28,} 69,70$

262

$$
k_{\mathrm{SA}}=\frac{k_{\mathrm{obs}}}{A}
$$




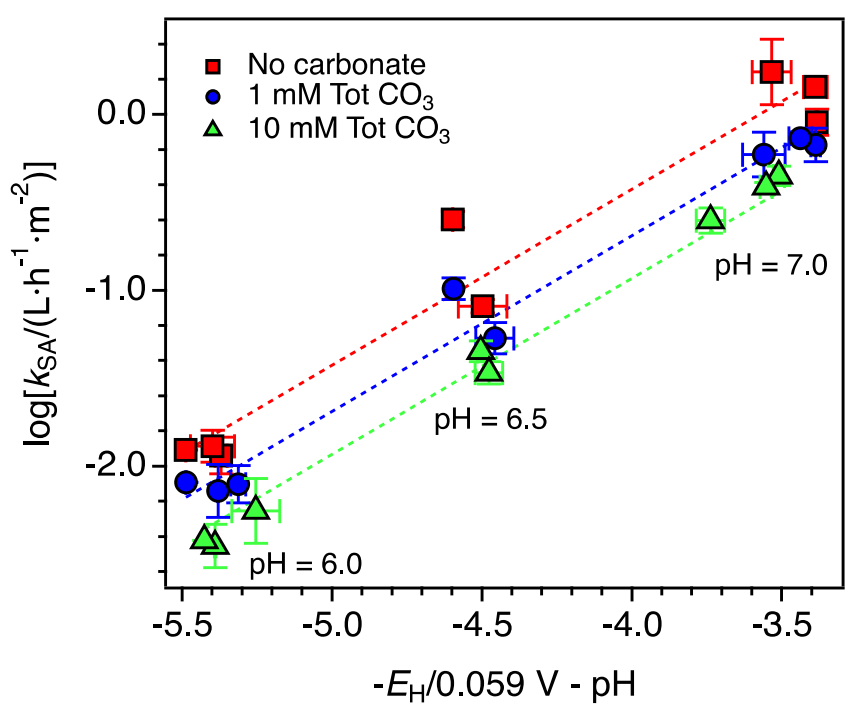

Figure 4. Linear free energy relationship between $\log \left(k_{\mathrm{SA}}\right)$ values and $E_{\mathrm{H}}$ and $\mathrm{pH}$ values. The slope of the line was held at 1 during the least-square linear regression. Error bars represent the two values measured from duplicate reactors, and points represent the average. The dash lines represent the linear fits: $r^{2}=0.95$ (red), 0.98 (blue), and 0.99 (green).

where $A$ is the surface area of goethite $\left(\mathrm{m}^{2} / \mathrm{L}\right)$ in the suspensions, which is calculated by multiplying

264 the goethite BET specific surface area $\left(\mathrm{m}^{2} / \mathrm{g}\right)$ by the goethite mass loading $(\mathrm{g} / \mathrm{L})$. The $k_{\mathrm{SA}}$ values

265 consequently have units of $\mathrm{L} \cdot \mathrm{h}^{-1} \cdot \mathrm{m}^{-2}$. We graphed $\log \left(k_{\mathrm{SA}}\right)$ values as a function of $\boldsymbol{E}_{\mathrm{H}}$ and $\mathrm{pH}$ values

266 based on the linear free energy relationship shown in Figure S1A and expressed in eq. 1 (Figure 4),

267 with the slope terms $\left(a\right.$ and $b$ ) held constant at $-1 .{ }^{28}$ Floating both the slopes and y-intercepts during

268 fitting yielded slopes close to 1 (no carbonate: $1.00 \pm 0.10,1 \mathrm{mM}$ total carbonate: $0.99 \pm 0.06,10$

269 mM total carbonate: $1.09 \pm$ 0.02; Figure S8). Note the data points cluster separately with respect to

$270 \mathrm{pH}$ because the $\mathrm{pH}$ has a substantial impact on the thermodynamic driving force of nitrobenzene

271 reduction by oxide-bound $\mathrm{Fe}^{2+} .{ }^{28}$ Plotting the data in this way clearly revealed that carbonate did not

272 affect the slope of the free energy relationship, indicating that carbonate did not change the

273 mechanisms and rate-limiting step of the redox reaction between nitrobenzene and oxide-bound

274 $\mathrm{Fe}^{2+} \cdot{ }^{28}$ We further confirmed that carbonate did not affect the slope in the free energy relationship

275 by performing a 1:1 correlation of $\log \left(\mathrm{k}_{\mathrm{SA}}\right)$ values in carbonate-present vs. carbonate-free systems, 
276 which yielded two straight line with slope values also equal to 1 within error (i.e., $1.02 \pm 0.06$ and $277 \quad 0.98 \pm 0.08$, Figure S9).$^{10}$

Carbonate did, however, change the y-intercept of the linear free energy relationship (i.e.,

279 the $c$ term in eq. 1), with $c$ values lower at higher carbonate concentrations (when the slope was held 280 at 1$): 3.57 \pm 0.08$ (no carbonate), $3.31 \pm 0.05(1 \mathrm{mM}$ total carbonate), and $3.07 \pm 0.03(10 \mathrm{mM})$.

281 These values reflect an average decrease in $k_{\mathrm{SA}}$ by a factor of $1.9 \pm 0.8 \mathrm{in} 1 \mathrm{mM}$ total carbonate and 282 a factor of $3.3 \pm 1.1 \mathrm{in} 10 \mathrm{mM}$ total carbonate, relative to $0 \mathrm{mM}$ total carbonate. This trend indicates 283 that carbonate decreased the number of reactive sites and/or the frequency of interactions between 284 nitrobenzene and reactive sites because we did not observe any-change in the $\boldsymbol{E}_{\mathrm{H}}^{0}$ values (Figure 3 ). 285 This observation led us to determine how carbonate influenced the reactive surface area of goethite 286 by examining its role in particle aggregation.

\section{Role of Carbonate in Goethite Aggregation}

288 To determine if carbonate altered the reactive surface area of goethite, we investigated how the 289 aggregation state of goethite and aqueous $\mathrm{Fe}^{2+}$ suspensions changed upon the addition of carbonate.

290 The mean hydrodynamic diameters of goethite aggregates became larger when carbonate was added, 291 as evidenced by dynamic light scattering (DLS) measurements (Figure 5A). At pH 6.0, DLS 292 measurements indicated that the mean hydrodynamic diameter of the goethite aggregates increased 293 from $1.26 \pm 0.02 \mu \mathrm{m}(0 \mathrm{mM}$ total carbonate) to $4.8 \pm 0.7 \mu \mathrm{m}(10 \mathrm{mM})$ (Figure 5A). Carbonate also 294 caused goethite to aggregate at pH $6.5(0 \mathrm{mM}: 2.6 \pm 0.3 \mu \mathrm{m}, 10 \mathrm{mM}: 6.2 \pm 0.5 \mu \mathrm{m})$ and pH $7.0(0$ $295 \mathrm{mM}: 3.6 \pm 0.7 \mu \mathrm{m}, 10 \mathrm{mM}: 5.5 \pm 0.7 \mu \mathrm{m})$. Note that calculated hydrodynamic diameters from DLS 296 measurements made at pH 6.5 and 7.0 may have contained some error, as the diameters approached 297 the quantitative detection limit of DLS $(\sim 10 \mu \mathrm{m})$ and sedimentation was visually apparent during the 298 measurements. ${ }^{31}$ Attempts to decrease sedimentation and aggregate sizes by decreasing the goethite 

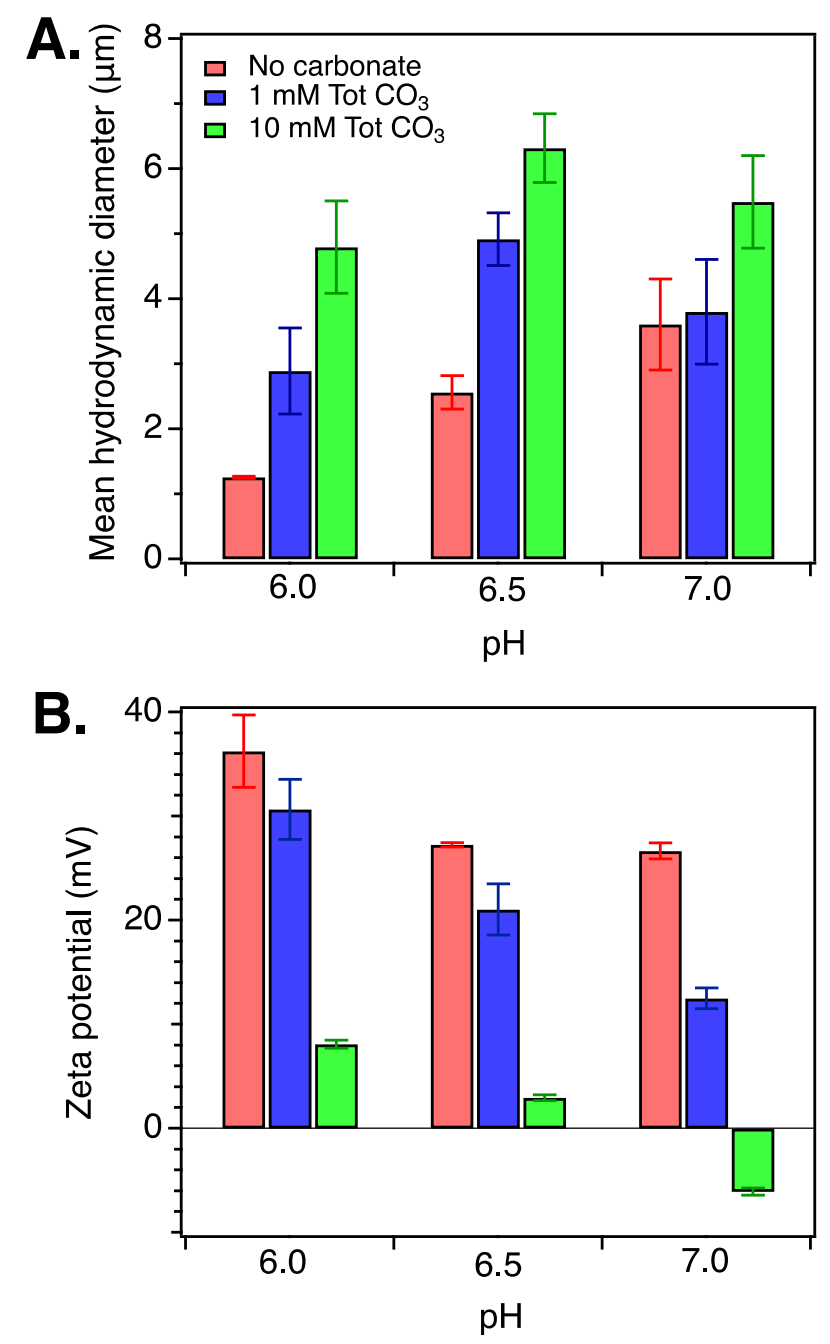

Figure 5. Impact of carbonate on the mean hydrodynamic diameters (A) and zeta potentials (B) of goethite in the presence of $\mathrm{Fe}_{(\mathrm{aq})}^{2+}$ at different $\mathrm{pH}$ values. Error bars represent standard deviations from triplicate measurements. Experimental conditions: $1 \mathrm{~g} / \mathrm{L}$ goethite, $0.2 \mathrm{mM} \mathrm{Fe}_{(\mathrm{aq})}^{2+}, 25 \mathrm{mM} \mathrm{KCl}$, and $25 \mathrm{mM}$ MES or MOPS buffer.

299 loading in solution were unsuccessful (data not shown). Despite the potential for quantitative artifacts

300 in the DLS analyses, the data clearly demonstrated that carbonate increased goethite aggregations.

$301 \quad$ We also measured goethite aggregation state using laser diffraction, which has a wider

302 detection range $(10 \mathrm{~nm}-3500 \mu \mathrm{m}),{ }^{62}$ but requires the samples to be exposed to air during analysis.

303 These measurements confirmed that carbonate induced aggregation (Figure S10). At pH 6.0, the 304 mean diameter of goethite aggregates increased from $2.4 \pm 0.1(0 \mathrm{mM}$ total carbonate $)$ to $5.0 \pm 0.1$ 
$305 \mu \mathrm{m}(10 \mathrm{mM}$ total carbonate), consistent with the DLS results. Similarly, laser diffractions 306 measurements also indicated that carbonate induced goethite aggregation at pH 6.5 (0 mM: $3.3 \pm$ $3070.1,10 \mathrm{mM}: 4.9 \pm 0.1)$ and $\mathrm{pH} 7.0(0 \mathrm{mM}: 3.0 \pm 0.2 \mu \mathrm{m}, 10 \mathrm{mM}: 4.3 \pm 0.1 \mu \mathrm{m})$, although the 308 magnitude of the effect was smaller than what we measured with DLS. We suspect the laser 309 diffraction measurements may have been affected by $\mathrm{Fe}^{2+}$ oxidation due to air exposure during 310 analysis. Prior work found that $\mathrm{Fe}^{2+}$ oxidation by oxygen changes the surface charge and aggregation 311 states of goethite. ${ }^{39}$

We examined if the reason carbonate increased goethite aggregation was that it formed 313 surface complexes on the goethite surface that altered the particles' surface charge. ${ }^{33,71}$ We tested 314 this hypothesis by performing zeta potential measurements on the suspensions used for DLS 315 experiments (Figure 5B). Over pH 6.0 to 7.0, carbonate lowered the surface charge of goethite, 316 bringing it closer to zero thus favoring particle aggregation by decreasing interparticle repulsive forces. 317 The point of zero charge of goethite has been reported to be approximately $9.0,{ }^{72}$ but the presence 318 of $10 \mathrm{mM}$ carbonate lowered it to a value between 6.5 to 7.0 (Figure 5B). Prior work has reported 319 the following inner-sphere surface complexation reactions of carbonate interacting with goethite 320 surfaces: ${ }^{33}$

$$
\equiv \mathrm{FeOH}+\mathrm{CO}_{3}^{2-}+2 \mathrm{H}^{+} \rightleftharpoons \equiv \mathrm{FeOCOOH}+\mathrm{H}_{2} \mathrm{O} \log (K)=18.29
$$

In addition, carbonate likely formed outer-sphere complexes in the double layer of goethite particles 326 through electrostatic interaction and neutralized positively charged goethite surface. Our results are 
327 consistent with carbonate forming surface complexes on goethite and inducing aggregation, yet

328 interestingly our earlier results in Figure 2 indicated that $\mathrm{Fe}^{2+}$ and carbonate did not compete for 329 sorption sites with $0.2 \mathrm{mM}$ total $\mathrm{Fe}^{2+}$. Given the strong evidence for interfacial electron-transfer 330 between $\mathrm{Fe}^{2+}$ and iron oxides, we speculate that this observation may be a result of $\mathrm{Fe}^{2+}$ uptake extent 331 being controlled by the redox properties of the iron oxide as opposed to surface complexation 332 associated with the number of surface sites. ${ }^{71-73}$

\section{Correcting the Reactive Surface Area of Goethite}

334 As discussed above, the linear free energy relationships in Figure 4 were developed using a $k_{\text {SA }}$ value 335 that was calculated based on the BET surface area of dry goethite (eq. 5). However, the actual 336 reactive surface area of goethite in aqueous suspensions appeared to vary with respect to the total 337 carbonate concentration due to aggregation. To account for aggregation in the free energy 338 relationship, we normalized nitrobenzene reduction rate constant $\left(k_{\mathrm{obs}}\right)$ with the calculated goethite 339 specific surface area in aqueous suspension from DLS and laser diffraction measurements. This 340 normalization required us to make an approximation that the goethite aggregates, which likely 341 consisted of loosely and irregularly bound rod-shaped particles, ${ }^{38}$ could be described as spherical

342 particles. This approximation would be valid if the actual reactive surface area of the aggregate is

343 linearly proportional to the calculated surface area when assuming the aggregates are spherical. Using

344 this approximation, we calculated the geometric specific surface area $\left(S S A_{\mathrm{aq}}\right)$ based on the mean 345 diameters $(d)$ of equivalent spheres of goethite: ${ }^{73,74}$

$$
S S A_{\mathrm{aq}}=\frac{4 \pi\left(\frac{d_{2}}{2}\right)^{2}}{\rho_{3}^{4} \pi\left(\frac{d_{2}}{3}\right)^{3}}=\frac{6}{\rho d}
$$




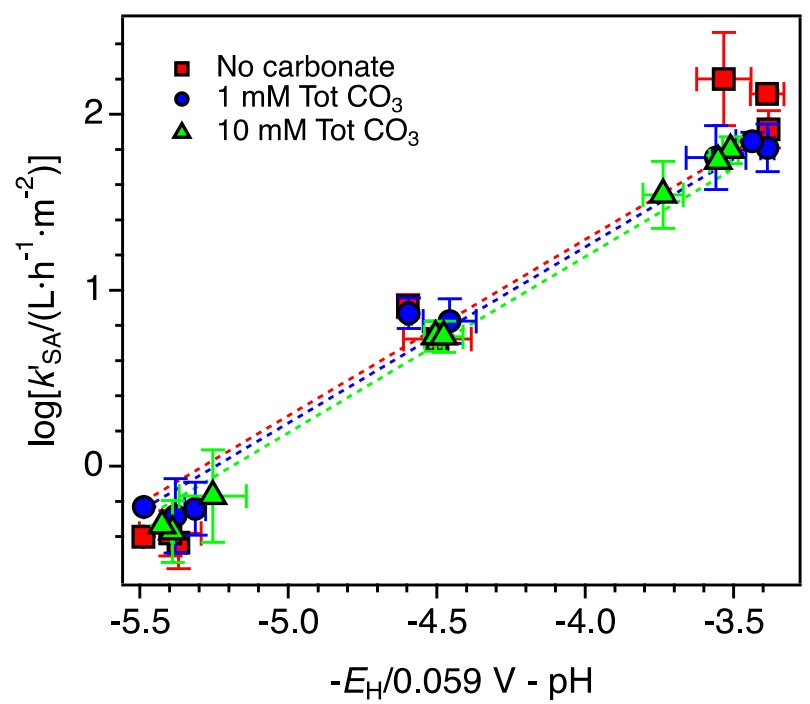

Figure 6. Impact of carbonate on the logarithms of the calibrated surface-area-normalized reaction rate constants $\left(\log \left(k_{\mathrm{SA}}^{\prime}\right)\right)$ based on DLS results as a function of $E_{\mathrm{H}}$ and $\mathrm{pH}$ values of $\mathrm{Fe}_{(\mathrm{aq})}^{2+}-$ goethite suspension for nitrobenzene reduction. Dashed lines represent the linear fits: $r^{2}=0.94$ (red), 0.98 (blue), and 0.99 (green). The slopes were held at 1 during fitting. When the slopes were allowed to float, they reached values close to 1 , with the small deviations attributed to experimental error.

347 where $\rho$ represents the density of goethite $\left(4.26 \mathrm{~g} / \mathrm{cm}^{3}\right){ }^{75}$ The calculated $S S A_{\mathrm{aq}}$ values from DLS

348 and laser diffraction ranged from 0.21 to $1.13 \mathrm{~m}^{2} / \mathrm{g}$, depending on the $\mathrm{pH}$ and total carbonate 349 concentrations. The $\boldsymbol{S} \boldsymbol{S} \boldsymbol{A}_{\text {aq }}$ values were much lower than the BET specific surface area value 350 measured for the dry particles $\left(36 \mathrm{~m}^{2} / \mathrm{g}\right)$, which was likely due to the aggregation and our simplistic 351 approximation that the aggregates were spherical. calibrated surface-area-normalized reaction rate constant $\left(\log \left[k_{\mathrm{SA}}^{\prime}\right]\right)$ :

355 where $m_{\mathrm{L}}$ is mass loading $(\mathrm{g} / \mathrm{L})$ of goethite. We graphed $\log \left(k_{\mathrm{SA}}^{\prime}\right)$ values as a function of $\boldsymbol{E}_{\mathrm{H}}$ and $\mathrm{pH}$ 356 values based on the linear free energy relationship (eq.1). After the calibration based on DLS results, 357 the scattered data points in Figure 4 closely converged for different carbonate concentrations (Figure 
358 6), which was quantitatively reflected by the similarity among the fitted y-intercepts $(c$ term): $5.29 \pm$

$3590.10(0 \mathrm{mM}), 5.25 \pm 0.04(1 \mathrm{mM})$, and $5.19 \pm 0.04(10 \mathrm{mM})$. Calibration based on laser diffraction

360 results also highly reduced scatter among the data (Figure S11), although they converged to a lesser

361 extent. These results indicate that the loss of the reactive surface area due to goethite aggregation was

362 the primary reason that nitrobenzene reduction slowed in the presence of carbonate. Therefore, we

363 concluded that the main mechanism by which carbonate slows nitrobenzene reduction by $\mathrm{Fe}^{2+}{ }_{-}$

364 bound to goethite is via particle aggregation caused by carbonate forming surface complexes on the

365 goethite surface that decrease the positive surface charge of goethite.

\section{Environmental implications}

367 Our results indicate that the predominant way in which carbonate alters the reduction rates of

368 nitroaromatic compounds by oxide-bound $\mathrm{Fe}^{2+}$ is by changing particulate aggregation state.

369 Carbonate increased goethite aggregation, which decreased the number of reactive sites on goethite

370 surfaces. We did not observe any evidence suggesting that carbonate affected the nitrobenzene

371 reduction mechanism, which would have changed the slope of the linear free energy relationship.

372 The effect that carbonate has on iron oxide particle aggregation will be highly specific to the iron

373 oxide present because aggregation behavior depends on the point of zero charge of an iron oxides,

374 which is oxide-specific. ${ }^{75}$ Reported point of zero charge values for goethite range between $8.9-9.4 .^{75}$

375 Other iron oxides have far lower point of zero charges, such as magnetite $(6.3-7.1)$ and

376 lepidocrocite $(6.7-7.45) \cdot{ }^{75}$ Given the differences in point of zero charge, iron oxides likely have

377 distinctive surface charges under environmentally relevant conditions, which affects surface

378 complexation of carbonate on iron oxides. Consequently, carbonate will likely affect their 379 aggregation behavior differently. 
More generally, our results offer evidence to support the use of free energy relationships to understand how groundwater constituents alter pollutant reduction rates by oxide-bound $\mathrm{Fe}^{2+}$ mechanistically. By constructing a free energy relationship that relates reduction rates to the thermodynamic driving force of the reaction, one can differentiate between how a groundwater constituent may change a reaction pathway (as evidenced by a change in the slope of the relationship)

385 or how it changes the number of reactive sites or the $\mathrm{Fe}^{2+}$ oxidation product that forms (as evidenced 386 by a change to the y-intercept). Coupling this analysis with $E_{\mathrm{H}}$ measurements could, for example, 387 allow one to discriminate among possible reasons that humic acids alter nitroaromatic reduction 388 rates by oxide-bound $\mathrm{Fe}^{2+}$, which has proven to be a difficult task. ${ }^{51-53}$ Humic acid may alter pollutant 389 reduction rates by aggregating particles, ${ }^{38,76}$ complexing aqueous $\mathrm{Fe}^{2+},{ }^{77}, 78$ changing $\mathrm{Fe}^{2+}$ oxidation 390 products, ${ }^{77}$ and/or by serving as electron shuttles. ${ }^{51}$ Coupling $E_{\mathrm{H}}$ measurements with conventionally 391 used approaches may allow researchers to discriminate among these possibilities for other classes of 392 contaminants as well, as was recently shown for chlorinated solvents reacted with reduced natural 393 sediments. ${ }^{16}$

\section{ASSOCIATED CONTENT}

395 The Supporting Information include compiled data from the literature, the XRD pattern of goethite, 396 the impact of carbonate on $\boldsymbol{E}_{\mathrm{H}}$ values, the goethite particle sizes and nitrobenzene reduction, the 397 impact of MOPS buffer on nitrobenzene reduction, and the predominance diagrams of $\mathrm{Fe}^{2+}$ species.

\section{ACKNOWLEDGEMENT}

399 The study was supported by U.S. National Science Foundation Program (CHE-1807703 to CAG) 400 Swiss National Science Foundation (Grant 200021_149283 to TBH). 


\section{REFERENCES}

402 1. Eary, L.; Rai, D., Chromate removal from aqueous wastes by reduction with ferrous

403 ion. Environmental Science \& Technology 1988, 22, (8), 972-977.

404 2. Buerge, I. J.; Hug, S. J., Influence of mineral surfaces on chromium (VI) reduction

$405 \quad$ by iron (II). Environmental Science \& Technology 1999, 33, (23), 4285-4291.

406 3. Latta, D. E.; Gorski, C. A.; Boyanov, M. I.; O’Loughlin, E. J.; Kemner, K. M.; Scherer,

5. Amonette, J. E.; Workman, D. J.; Kennedy, D. W.; Fruchter, J. S.; Gorby, Y. A.,

4. Myneni, S. C. B.; Tokunaga, T. K.; Brown, G., Abiotic selenium redox M. M., Influence of magnetite stoichiometry on UVI reduction. Environmental Science \& Technology 2012, 46, (2), 778-786.

transformations in the presence of Fe (II, III) oxides. Science 1997, 278, (5340), 1106 1109. Dechlorination of carbon tetrachloride by Fe (II) associated with goethite. Environ. Sci. Technol. 2000, 34, (21), 4606-4613.

6. Pecher, K.; Haderlein, S. B.; Schwarzenbach, R. P., Reduction of polyhalogenated methanes by surface-bound Fe (II) in aqueous suspensions of iron oxides. Environ. Sci. Technol. 2002, 36, (8), 1734-1741.

7. Strathmann, T. J.; Stone, A. T., Mineral surface catalysis of reactions between FeII and oxime carbamate pesticides. Geochim. Cosmochim. Acta 2003, 67, (15), 27752791.

8. Li, X.; Chen, Y.; Zhang, H., Reduction of nitrogen-oxygen containing compounds (NOCs) by surface-associated Fe (II) and comparison with soluble Fe (II) complexes. Chemical Engineering Journal 2019, 370, 782-791.

9. Elsner, M.; Schwarzenbach, R. P.; Haderlein, S., Reactivity of Fe(II)-Bearing Minerals toward Reductive Transformation of Organic Contaminants. Environmental Science \& Technology 2004, 38, 799-807.

10. Tratnyek, P. G.; Weber, E. J.; Schwarzenbach, R. P., Quantitative structure-activity relationships for chemical reductions of organic contaminants. Environmental Toxicology and Chemistry: An International Journal 2003, 22, (8), 1733-1742.

11. Amstaetter, K.; Borch, T.; Larese-Casanova, P.; Kappler, A., Redox transformation of arsenic by Fe (II)-activated goethite ( $\mathrm{\alpha}-\mathrm{FeOOH})$. Environmental science \& technology 2010, 44, (1), 102-108.

12. Jeon, B.-H.; Dempsey, B. A.; Burgos, W. D.; Barnett, M. O.; Roden, E. E., Chemical reduction of $\mathrm{U}$ (VI) by Fe (II) at the solid- water interface using natural and synthetic Fe (III) oxides. Environmental Science \& Technology 2005, 39, (15), 5642-5649. 
13. Melton, E. D.; Swanner, E. D.; Behrens, S.; Schmidt, C.; Kappler, A., The interplay of microbially mediated and abiotic reactions in the biogeochemical Fe cycle. Nature Reviews Microbiology 2014, 12, (12), 797-808.

14. Fan, D.; Bradley, M. J.; Hinkle, A. W.; Johnson, R. L.; Tratnyek, P. G., Chemical reactivity probes for assessing abiotic natural attenuation by reducing iron minerals. Environmental science \& technology 2016, 50, (4), 1868-1876.

15. Bussan, A. L.; Strathmann, T. J., Influence of organic ligands on the reduction of polyhalogenated alkanes by iron (II). Environmental science \& technology 2007, 41, (19), 6740-6747.

16. Kocur, C. M.; Fan, D.; Tratnyek, P. G.; Johnson, R. L., Predicting Abiotic Reduction Rates Using Cryogenically Collected Soil Cores and Mediated Reduction Potential Measurements. Environmental Science \& Technology Letters 2019.

17. Wilkin, R. T.; Su, C.; Ford, R. G.; Paul, C. J., Chromium-removal processes during groundwater remediation by a zerovalent iron permeable reactive barrier. Environmental science \& technology 2005, 39, (12), 4599-4605.

18. Liang, S.; Kao, C.; Kuo, Y.; Chen, K.; Yang, B., In situ oxidation of petroleumhydrocarbon contaminated groundwater using passive ISCO system. water research 2011, 45, (8), 2496-2506.

19. Amonette, J. E.; Workman, D. J.; Kennedy, D. W.; Fruchter, J. S.; Gorby, Y. A., Dechlorination of Carbon Tetrachloride by Fe(II) Associated with Goethite. Environmental Science \& Technology 2000, 34, (21), 4606-4613.

20. Strathmann, T. J.; Stone, A. T., Mineral surface catalysis of reactions between Fe(II) and oxime carbamate pesticides. Geochimica Et Cosmochimica Acta 2003, 67, (15), 2775-2791.

21. Klausen, J.; Trober, S. P.; Haderlein, S. B.; Schwarzenbach, R. P., Reduction of substituted nitrobenzenes by $\mathrm{Fe}(\mathrm{II})$ in aqueous mineral suspensions. Environmental Science \& Technology 1995, 29, (9), 2396-2404.

22. Rügge, K.; Hofstetter, T. B.; Haderlein, S. B.; Bjerg, P. L.; Knudsen, S.; Zraunig, C.; Mosbæk, H.; Christensen, T. H., Characterization of Predominant Reductants in an Anaerobic Leachate-Contaminated Aquifer by Nitroaromatic Probe Compounds. Environmental Science \& Technology 1998, 32, (1), 23-31.

23. Pecher, K.; Haderlein, S. B.; Schwarzenbach, R. P., Reduction of polyhalogenated methanes by surface-bound $\mathrm{Fe}(\mathrm{II})$ in aqueous suspensions of iron oxides. Environmental Science \& Technology 2002, 36, (8), 1734-1741.

24. Cui, D.; Eriksen, T. E., Reduction of pertechnetate by ferrous iron in solution: Influence of sorbed and precipitated Fe (II). Environmental science \& technology 1996, 30, (7), 2259-2262. 
25. Liger, E.; Charlet, L.; Van Cappellen, P., Surface catalysis of uranium(VI) reduction by iron(II). Geochimica et Cosmochimica Acta 1999, 63, (19-20), 2939-2955.

26. Colón, D.; Weber, E. J.; Anderson, J. L., QSAR Study of the Reduction of Nitroaromatics by Fe(II) Species. Environmental Science \& Technology 2006, 40, (16), 4976-4982.

27. Jones, A. M.; Kinsela, A. S.; Collins, R. N.; Waite, T. D., The reduction of 4chloronitrobenzene by $\mathrm{Fe}(\mathrm{II})-\mathrm{Fe}(\mathrm{III})$ oxide systems - correlations with reduction potential and inhibition by silicate. Journal of Hazardous Materials 2016, 320, 143149.

28. Stewart, S. M.; Hofstetter, T. B.; Joshi, P.; Gorski, C. A., Linking thermodynamics to pollutant reduction kinetics by $\mathrm{Fe} 2+$ bound to iron oxides. Environmental science \& technology 2018, 52, (10), 5600-5609.

29. Strehlau, J. H.; Schultz, J. D.; Vindedahl, A. M.; Arnold, W. A.; Penn, R. L., Effect of nonreactive kaolinite on 4-chloronitrobenzene reduction by Fe (II) in goethitekaolinite heterogeneous suspensions. Environmental Science: Nano 2017, 4, (2), 325334 .

30. Gorski, C. A.; Edwards, R.; Sander, M.; Hofstetter, T. B.; Stewart, S. M., Thermodynamic characterization of iron oxide-aqueous $\mathrm{Fe} 2+$ redox couples. Environmental science \& technology 2016, 50, (16), 8538-8547.

31. Stemig, A. M.; Do, T. A.; Yuwono, V. M.; Arnold, W. A.; Penn, R. L., Goethite nanoparticle aggregation: effects of buffers, metal ions, and 4-chloronitrobenzene reduction. Environmental Science: Nano 2014, 1, (5), 478-487.

32. Chun, C. L.; Penn, R. L.; Arnold, W. A., Kinetic and microscopic studies of reductive transformations of organic contaminants on goethite. Environmental Science \& Technology 2006, 40, (10), 3299-3304.

33. Vikesland, P. J.; Valentine, R. L., Iron oxide surface-catalyzed oxidation of ferrous iron by monochloramine: Implications of oxide type and carbonate on reactivity. Environmental science \& technology 2002, 36, (3), 512-519.

34. Liger, E.; Charlet, L.; Van Cappellen, P., Surface catalysis of uranium (VI) reduction by iron (II). Geochim. Cosmochim. Acta 1999, 63, (19-20), 2939-2955.

35. Hofstetter, T. B.; Heijman, C. G.; Haderlein, S. B.; Holliger, C.; Schwarzenbach, R. P., Complete reduction of TNT and other (poly) nitroaromatic compounds under iron-reducing subsurface conditions. Environ. Sci. Technol. 1999, 33, (9), 1479-1487.

36. Jones, A. M.; Kinsela, A. S.; Collins, R. N.; Waite, T. D., The reduction of 4chloronitrobenzene by $\mathrm{Fe}$ (II)-Fe (III) oxide systems-correlations with reduction potential and inhibition by silicate. J. Hazard. Mater. 2016, 320, 143-149. 
37. Vindedahl, A. M.; Strehlau, J. H.; Arnold, W. A.; Penn, R. L., Organic matter and iron oxide nanoparticles: aggregation, interactions, and reactivity. Environmental Science: Nano 2016, 3, (3), 494-505.

38. Vindedahl, A. M.; Stemig, M. S.; Arnold, W. A.; Penn, R. L., Character of humic substances as a predictor for goethite nanoparticle reactivity and aggregation. Environ. Sci. Technol. 2016, 50, (3), 1200-1208.

39. Strehlau, J. H.; Stemig, M. S.; Penn, R. L.; Arnold, W. A., Facet-dependent oxidative goethite growth as a function of aqueous solution conditions. Environ. Sci. Technol. 2016, 50, (19), 10406-10412.

40. Huang, J.; Wang, Q.; Wang, Z.; Zhang, H., Interactions and reductive reactivity in ternary mixtures of $\mathrm{Fe}$ (II), goethite, and phthalic acid based on a combined experimental and modeling approach. Langmuir 2019, 35, (25), 8220-8227.

41. Huang, J.; Dai, Y.; Liu, C.-C.; Zhang, H., Effects of Second Metal Oxides on SurfaceMediated Reduction of Contaminants by Fe (II) with Iron Oxide. ACS Earth and Space Chemistry 2019, 3, (5), 680-687.

42. Felmy, A. R.; Moore, D. A.; Rosso, K. M.; Qafoku, O.; Rai, D.; Buck, E. C.; Ilton, E. S., Heterogeneous reduction of $\mathrm{PuO} 2$ with Fe (II): Importance of the Fe (III) reaction product. Environ. Sci. Technol. 2011, 45, (9), 3952-3958.

43. Felmy, A. R.; Ilton, E. S.; Rosso, K. M.; Zachara, J. M., Interfacial reactivity of radionuclides: emerging paradigms from molecular-level observations. Mineralogical Magazine 2011, 75, (4), 2379-2391.

44. Schwertmann, U.; Carlson, L.; Fechter, H., Iron oxide formation in artificial ground waters. Aquatic Sciences-Research Across Boundaries 1984, 46, (2), 185-191.

45. Larese-Casanova, P.; Kappler, A.; Haderlein, S. B., Heterogeneous Oxidation of $\mathrm{Fe}(\mathrm{II})$ on Iron Oxides in Aqueous Systems: Identification and Controls of Fe(III) Product Formation. Geochimica et Cosmochimica Acta 2012, 91, 171-186.

46. Jones, A. M.; Griffin, P. J.; Collins, R. N.; Waite, T. D., Ferrous iron oxidation under acidic conditions-The effect of ferric oxide surfaces. Geochimica et Cosmochimica Acta 2014, 145, 1-12.

47. Colón, D.; Weber, E. J.; Anderson, J. L., QSAR study of the reduction of nitroaromatics by Fe (II) species. Environ. Sci. Technol. 2006, 40, (16), 4976-4982.

48. Hartenbach, A. E.; Hofstetter, T. B.; Aeschbacher, M.; Sander, M.; Kim, D.; Strathmann, T. J.; Arnold, W. A.; Cramer, C. J.; Schwarzenbach, R. P., Variability of nitrogen isotope fractionation during the reduction of nitroaromatic compounds with dissolved reductants. Environ. Sci. Technol. 2008, 42, (22), 8352-8359. 
49. Hartenbach, A.; Hofstetter, T. B.; Berg, M.; Bolotin, J.; Schwarzenbach, R. P., Using nitrogen isotope fractionation to assess abiotic reduction of nitroaromatic compounds. Environmental science \& technology 2006, 40, (24), 7710-7716.

50. Hofstetter, T. B.; Neumann, A.; Arnold, W. A.; Hartenbach, A. E.; Bolotin, J.; Cramer, C. J.; Schwarzenbach, R. P., Substituent effects on nitrogen isotope fractionation during abiotic reduction of nitroaromatic compounds. Environmental science \& technology 2008, 42, (6), 1997-2003.

51. Colón, D.; Weber, E. J.; Anderson, J. L., Effect of natural organic matter on the reduction of nitroaromatics by Fe (II) species. Environmental science \& technology 2008, 42, (17), 6538-6543.

52. Luan, F.; Xie, L.; Li, J.; Zhou, Q., Abiotic reduction of nitroaromatic compounds by $\mathrm{Fe}(\mathrm{II})$ associated with iron oxides and humic acid. Chemosphere 2013, 91, (7), 10351041 .

53. Huang, J.; Cao, J.; Tu, N.; Dong, H.; Li, J.; Shou, J.; Li, Y., Effect of surfactants on the removal of nitrobenzene by Fe-bearing montmorillonite/Fe (II). Journal of colloid and interface science 2019, 533, 409-415.

54. Cao, J.; Huang, J.; Dong, H.; Li, J.; Shou, J.; Li, Y., Effects of surfactants on the removal of nitrobenzene by Fe (II) sorbed on goethite. J. Colloid Interface Sci. 2019, $552,764-770$.

55. King, D. W., Role of carbonate speciation on the oxidation rate of Fe (II) in aquatic systems. Environmental Science \& Technology 1998, 32, (19), 2997-3003.

56. Gorski, C. A.; Klüpfel, L.; Voegelin, A.; Sander, M.; Hofstetter, T. B., Redox properties of structural $\mathrm{Fe}$ in clay minerals. 2. Electrochemical and spectroscopic characterization of electron transfer irreversibility in ferruginous smectite, SWa-1. Environ. Sci. Technol. 2012, 46, (17), 9369-9377.

57. Schwertmann, U.; Cornell, R. M., Iron oxides in the laboratory: preparation and characterization. John Wiley \& Sons: 2008.

58. Brunauer, S.; Emmett, P. H.; Teller, E., Adsorption of gases in multimolecular layers. Journal of the American chemical society 1938, 60, (2), 309-319.

59. Jiang, C. Z.; Tosca, N. J., Fe (II)-carbonate precipitation kinetics and the chemistry of anoxic ferruginous seawater. Earth. Planet. Sci. Lett. 2019, 506, 231-242.

60. Tamura, H.; Goto, K.; Yotsuyanagi, T.; Nagayama, M., Spectrophotometric determination of iron (II) with 1, 10-phenanthroline in the presence of large amounts of iron (III). Talanta 1974, 21, (4), 314-318. 
578

61. Koppel, D. E., Analysis of macromolecular polydispersity in intensity correlation spectroscopy: the method of cumulants. The Journal of Chemical Physics 1972, 57, (11), 4814-4820.

62. Malvern Instruments Ltd, M., Mastersizer 3000 User Manual. 2015.

63. Gorski, C. A.; Nurmi, J. T.; Tratnyek, P. G.; Hofstetter, T. B.; Scherer, M. M., Redox behavior of magnetite: Implications for contaminant reduction. Environmental Science \& Technology 2009, 44, (1), 55-60.

64. Huang, J.; Wang, Q.; Wang, Z.; Zhang, H. J., Interactions and Reductive Reactivity in Ternary Mixtures of Fe (II), Goethite, and Phthalic Acid based on a Combined Experimental and Modeling Approach. Langmuir 2019.

65. Villalobos, M.; Leckie, J. O., Surface complexation modeling and FTIR study of carbonate adsorption to goethite. Journal of Colloid and Interface Science 2001, 235, (1), 15-32.

66. van Geen, A.; Robertson, A. P.; Leckie, J. O., Complexation of carbonate species at the goethite surface: Implications for adsorption of metal ions in natural waters. Geochimica et Cosmochimica Acta 1994, 58, (9), 2073-2086.

67. Sander, M.; Hofstetter, T. B.; Gorski, C. A., Electrochemical analyses of redox-active iron minerals: a review of nonmediated and mediated approaches. Environ. Sci. Technol. 2015, 49, (10), 5862-5878.

68. Gorski, C. A.; Aeschbacher, M.; Soltermann, D.; Voegelin, A.; Baeyens, B.; Marques Fernandes, M.; Hofstetter, T. B.; Sander, M., Redox properties of structural Fe in clay minerals. 1. Electrochemical quantification of electron-donating and-accepting capacities of smectites. Environmental science \& technology 2012, 46, (17), 9360-9368.

69. Arnold, W. A.; Roberts, A. L., Pathways and kinetics of chlorinated ethylene and chlorinated acetylene reaction with Fe (0) particles. Environ. Sci. Technol. 2000, 34, (9), 1794-1805.

70. Scherer, M. M.; Balko, B. A.; Gallagher, D. A.; Tratnyek, P. G., Correlation analysis of rate constants for dechlorination by zero-valent iron. Environmental science \& technology 1998, 32, (19), 3026-3033.

71. Villalobos, M.; Trotz, M. A.; Leckie, J. O., Surface complexation modeling of carbonate effects on the adsorption of $\mathrm{Cr}$ (VI), $\mathrm{Pb}$ (II), and $\mathrm{U}$ (VI) on goethite. Environmental science \& technology 2001, 35, (19), 3849-3856.

72. Villalobos, M.; Leckie, J. O., Carbonate adsorption on goethite under closed and open CO2 conditions. Geochimica et Cosmochimica Acta 2000, 64, (22), 3787-3802.

73. White, A. F.; Peterson, M. L., Role of reactive-surface-area characterization in geochemical kinetic models. In ACS Publications: 1990. 
614 74. Liu, J.; Aruguete, D. M.; Murayama, M.; Hochella Jr, M. F., Influence of size and 615 aggregation on the reactivity of an environmentally and industrially relevant 616 nanomaterial (PbS). Environmental science \& technology 2009, 43, (21), 8178-8183.

617 75. Cornell, R. M.; Schwertmann, U., The iron oxides: structure, properties, reactions, $618 \quad$ occurrences and uses. John Wiley \& Sons: 2003.

619 76. Baalousha, M., Aggregation and disaggregation of iron oxide nanoparticles: influence 620 of particle concentration, $\mathrm{pH}$ and natural organic matter. Science of the total Environment 2009, 407, (6), 2093-2101.

622 77. Daugherty, E. E.; Gilbert, B.; Nico, P. S.; Borch, T., Complexation and Redox Buffering of Iron(II) by Dissolved Organic Matter. Environmental Science \& Technology 2017, 51, (19), 11096-11104.

625 78. Rose, A. L.; Waite, T. D., Kinetics of iron complexation by dissolved natural organic matter in coastal waters. Marine chemistry 2003, 84, (1), 85-103. 